\title{
Mangrove Forest Green Belt as Disaster Mitigation of Sea Level Rise in Coastal Zones
}

\author{
Sumarmi \\ Purwanto \\ Faculty of Social Sciences, Universitas Negeri Malang, Indonesia \\ Email: sumarmi.fis@um.ac.id; purwanto.fis@um.ac.id
}

\author{
Doi:10.5901/mjss.2017.v8n2p219
}

\section{Abstract}

The purpose of this study is to: (1) identify the disaster in coastal areas due to sea level rise (2) identify the structural disaster mitigation conducted by coastal communities, and (3) identify the adaptation of Green Belt Business Group (Kelompok Usaha Bersama "KUB" Sabuk Hijau) in overcoming the disaster caused by sea level rise. This study used a qualitative approach with the methods of observation, in-depth interview, FGD, and documentation. The results showed that the disasters faced by coastal communities in the study area are: the overflow of seawater up to the houses, wells became salty and unusable, ponds destroyed by flooding, the failure of the salt farming crop, fisherman's low income. The mitigation structure which was done is by making a green belt of 44 hectares mangrove forests to reduce catastrophic losses. The activity was able to save the pond that was damaged, restore the salt farm, recover the coastal ecosystem, return the wells from saltiness so that it can be used again, keep the houses from flooding, and able to add the family incomes from the honey mangrove and coffee mangrove.

Keywords: Green Belt, mangrove management, disaster mitigation and adaptation

\section{Introduction}

Coastal area is a strategic place to develop the region. Sea level rise will erode the beaches, increase the frequency of flooding, increase the salinity of the river and groundwater, create high waves, rise up the temperature of the sea water and runoff, and other effects which may occur as a result of climate change. Those conditions affected the coastal area which is a subsystem of nature and social sub-system on the shore so that it cannot sustain life adequately (Kusnanto, 2011).

To manage the coastal area, Indonesian government issued the Law No. 1 of 2014 concerning the Management of Coastal Areas and Small Islands, with this following explanation: (1) Coastal area is the transition area between land and sea ecosystem affected by the changes in land and sea. (2) An ecosystem is the unity of a community of plants, animals, organisms and other non-organisms as well as the process which connects balance, stability, and productivity. (3) The Conservation of Coastal Areas and Small Islands is an attempt of protection, preservation, and utilization of Coastal Areas and Small Islands and the ecosystem within to ensure the existence, availability, and continuity of Coastal and Small Islands Resources while maintaining and improving the value and diversity quality. (4) Border Coast is the land along the banks with a width that is proportional to the shape and physical condition of the beach, a minimum of 100meters from the highest tide to the landward.

Coastal area is the area of interaction between the three elements of nature, namely, land, sea, and air. This area also serves as a buffer zone for many immigration animals (fish, shrimp, or birds) to find food, breed and raise their young. As a unique ecosystem, there are a few things to note as follows: (1) Coastal area is a region that has a very high carrying capacity so that this region becomes a concentration of a variety of human life. It is not by chance that many large cities are located on the coast. (2) As a result of a very high human activity in this region and due to its geographic position, the coastal area becomes vulnerable to environmental damage. (3) Damage to the coastal region will have a big impact on other regions. (Fachrul, http://tyasmelani.blogspot.com/2009/05/ekosistem-pesisir-pantai.html )

The problems above are closely related to the problems in coastal villages, it also related to the economic problems that exist in the society. Economic Development of Marine and Coastal includes: (1) Illegal Fishing, (2) the degradation of Coastal and Small Islands Resources (mangroves, coral reefs, sand miners, coastal reclamation, oil pollution, erosion and sedimentation, as well as (3) global climate change that affects the coastal and marine resources (Apridar, 2011).

According to Priwardhani (2013) and Diposaptono et.al (2009), the impacts of climate change for the environment 
are: (1) The indicators of annual temperature changes and in the last 20 years such as; a). Ice poles melting that cause a sea level rising b). Coral Bleaching (extinguish and bleach the coral reefs) apart as the result of potassium chemical usage. (2) The indicators of annual rainfall volume changes and in the last 20 years brings an impact on rain storms, floods, and abrasions. (3) The indicators of sea level rise impacted the lowland and marsh inundation, coastal erosion, flooding, extreme waves, and sea water intrusion into rivers and groundwater (Wibowo, 2015).

Mangrove forests and coral reefs play an important role in the coastal communities' sustainability. Bengen (2002) describes the functions and benefits of mangrove forests which also covers the ecological and economic functions. Ecological functions include: 1) the physical aspects, such as setting up the relationship mechanism between components in mangrove ecosystems or other ecosystems, acts as the coastal protection and also a flood control; 2) the chemical aspects which are the pollutant absorption, an energy source for organisms and as an organic material supply for the environment; 3) the biological aspect that is keeping the stability of aquatic biological resources productivity and availability. That function makes the mangrove forests as a source of coastal communities, including in rural coastal communities of Lembung-Galis, Kecamatan Pamekasan, Kabupaten Pamekasan.

The signs of global warming are already visible in Indonesia in the last 20 years, we have had three very long dry seasons that have an extremely harmful effect. To anticipate the impact of sea-level rise due to global warming which has a national scale and a long dimension of time, then the existence of a national spatial plan (Rencana Tata Ruang Wilayah Nasional or RTRWN) becomes very important. Broadly speaking, RTRWN contains a policy direction which includes: (a) the direction and policy of protected areas, (b) the policy direction for cultivation area in coastal regions.

The very rapid population which growth in coastal areas causing an increase in both individual and social needs. Every individual has always wanted to fulfill their needs; this fulfillment is the cause of environmental problems. Today's environmental issues are not only caused by human action but also the influence of global climate conditions (Sumarmi, 2012). Global climate conditions are causing such environmental damages, including the damage to the environment in coastal areas of Lembung-Galis, Madura. In order to keep on fulfilling their needs, people adapt and preserve the environmental conditions.

Similar problems also occurred in Lembung-Galis, Kecamatan Pamekasan, Kabupaten Pamekasan which are: The location of fish ponds or salt farm becomes damaged, embankments get broken down because it was not able to withstand the sea brunt. (2) Fish farmers and salt farmers are complaining, they also worried because they have to spend for about 5 up to 10 million rupiahs for each activity in one season to repair the damaged embankments. (3) The condition of water sources (wells) in average is very salty as if it cannot be used by the community. (4) The lives of the fishing communities are below the poverty line. (5) The condition of coastal environments is very hot and dry so that they feel not quite comfortable while carrying the daily activities. (6) It is rare to encounter sea birds because their habitat such as mangrove plants have not flourish yet. To overcome all those problems, it needs a mitigation to reduce the losses which were caused by the environmental problems.

Mitigation is the measures to reduce or minimize the impact of a disaster on a community. Natural disaster is a natural event that causes damage or casualties both property and life due to volcanic eruptions, earthquakes, landslides, tidal waves, floods, droughts, forest fires, high winds / hurricanes / typhoons, tsunamis, pests of forest, destruction of floras and faunas (ecological damage), and others (Directorate General of Coastal Areas and Small Islands, 2004)

Mitigation options aim at minimizing $\mathrm{CO} 2$ and other greenhouse gas emissions, in an effort to reduce the rate of increase in global temperature. On the other hand, adaptation options relate to the ability of the natural or human systems to handle the impact of the climate change and to adjust to its effects, seeking to eliminate the adverse consequences and take advantage of any beneficial outcomes (Alexandra V, 2015). More specifically, IPCC (2007) defines mitigation as an anthropogenic intervention to reduce the sources or enhance the sinks of GHGs. In parallel, adaptation refers to the ability to adjust to $\mathrm{CC}$, to moderate potential damage, to take advantages of emerging opportunities and/or to face the consequences.

Philosophically, disaster mitigation in coastal areas could be achieved through these following strategies: (a) a protective pattern, which is by making the beach building directly to "restrain the natural events that may occur". (b) an adaptive pattern, trying to adjust to the changing nature of coastal management that occurred. (c) a retreat pattern or donothing, to not fight against the natural dynamics but by "giving it up" to the natural processes and adjust the allocation in accordance with the conditions of natural changes that occur (Directorate General of Coastal Areas and Small Islands, 2004).

The physical countermeasures of structural disaster mitigation of sea level rise which can be done are: (1) creating a good system of coastal protection either static or dynamic such as the construction of dikes, seawall, revetment, groin, detached breakwater and mangrove planting. (2) Appointing or elevating any form of facilities and coastal land. (3) Move all forms of land facilities and the shore to a land that is safe from the sea water. (4) Adjusting the drainage 
system. (Directorate General of Coastal Areas and Small Islands, 2004).

\section{Methodology}

This study used the descriptive qualitative method. The data were obtained by analyzing library materials related to mangrove forests, disaster mitigation and adaptation, observation, in-depth interview, focus group discussion or FGD, and documentation. This qualitative study was aimed at Madura community in managing the mangroves in LembungGalis, Pamekasan coastal areas. The data used in this study were primary and secondary data. The primary data obtained by conducting interviews and FGD with Green Belt Business Group (Kelompok Usaha Bersama "KUB" Sabuk $\mathrm{Hijau}$ ) with several informants and observations during the on-site research. Secondary data were obtained by studying the literature that was related to this research.

The technique of the interviews which were conducted in order to obtain the data directly from the informant was a deep interview with interview guide which has been prepared to obtain such primary and directed data, also by using an open questionnaire. The question was in the form of the open interview which gave a flexibility for the informants to give their perspective or point of view freely and openly in order to obtain deeper data. Observation, this was done by observing a variety of situations and conditions in the field both physically, socially, economically, and culturally.

The data analysis model in qualitative research according to Creswell (2010: 277) are (1) The raw data (transcripts, field data, images, etc.). (2) Processing and preparing all the data to be analyzed. (3) Read all the data (4) Data coding. (5) Data description. (6) Connecting the themes or descriptions (grounded theory, case studies). (7) Interpreting themes or descriptions

\section{Research Results}

Among the islands in Indonesia, Madura island is classified as a dry, barren, not green, and less fertile area. This is because the composition of the soil is not good for plants. Due to extremely limited technical irrigation, the biggest agricultural land is in the form of moor or dry land, so the livelihood of the society is not oriented in agricultural land, but more to the trading activities and sea activities as fishermen. This phenomenon also occurs in the community of Lembung-Galis, Pamekasan. Located in the suburbs of Pamekasan with arid conditions and chalky area that looks barren in the dry season, only certain plants which can live in this season such as acacia and bamboo. Social rules on fishing communities already exist, even they have already coordinated with groups. They against the use of cyanide or bomb and prohibit destructive fishing and mangrove forests.

Barren land area has a tremendous impact, both in terms of social activities, economy, and livelihoods which are continuously choking the life of the coastal area community. The sea level rise which is not unstoppable goes into the houses of the community. The psychological distress of the communities in coastal areas is caused by the environment that is often flooded due to sea level rise (Sumarmi, 2014).

Mangrove forests in Madura spread along from Bangkalan, Sampang, Pamekasan and Sumenep where it can be seen in Figure 1. The most damaged mangrove forest is detected in Pamekasan. Its range is $\pm 1.000 \mathrm{Ha}$ and spread across the southern coastal districts from Tlanakan, Pademawu, Galis until Larangan. (https://rendezvoustrip.wordpress.com/2014/04/14/kopi-mangrove-kopinya-malam-jumat).

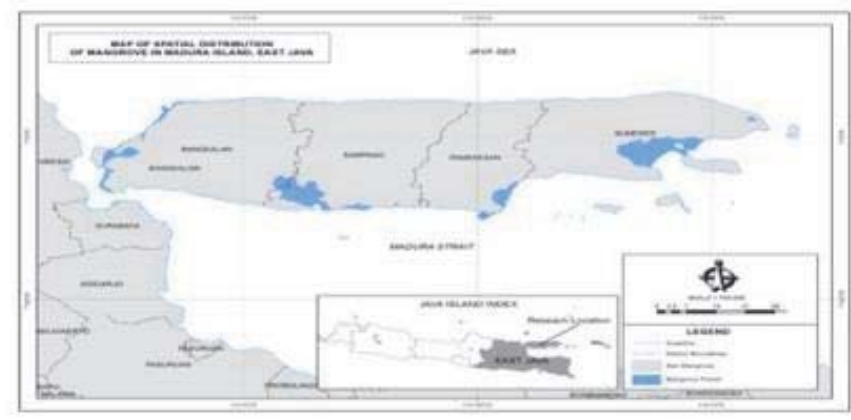

Figure 1. Distribution of Mangrove Forests in Madura Island 
Because of the guidance of the Department of Forestry Instructor, reforestation was done by involving the local villagers, especially fishermen and fish farmers. The reforestation was approached through the community leaders, forming such farmer groups and other programs which directly involve the local community. The approach which was conducted by the community leaders turned out to encourage the villagers to participate actively. The benefits which are immediately perceived is the increased income of fishermen and fish farmers as the positive impact from the proliferation of marine life such as fish, shrimp, clams, crabs and other aquatic organisms that live in the mangrove forest.

The irrigation system in Lembung-Galis is rain-fed. Rice and corn which they have planted depend entirely on rainfall due to the difficulty of freshwater. The farming methods and the equipment they use are very simple, they use hoes and plows to cultivate their farm. Unlike the farming communities, fishing communities have started to realize and understand the environment, especially coastal environments which have a direct relation with their activities and sources of livelihood. They consider that mangrove should not be cut down because it can erode the beaches and reduce their incomes which are the loss of fish, shrimps, and crabs.

The community formed the organization or business group on September 23, 2006, namely Kelompok Usaha Bersama "KUB" Sabuk Hijau or Green Belt Business Group - Desa Lembung, KUB Sumber Bahari - Desa Polagan, and KUB Pandan Wangi - Desa Pandan. It is aimed to develop a mangrove beekeeping, a mangrove coffee manufacture, the realization of new groups that have similar activities and become the subordinates, become a learning media of coastal environmental conservation for students due to an internship or research.

The creativity of Green Belt Business Group is that they have an extraordinary idea in preserving government programs, especially in terms of the environmental management. They do not stop planting the mangrove trees and disseminate a socialization to the public about the importance of mangrove trees. They also performed nurseries around the coast as well as monitor and maintenance the coastal area.

After doing some replanting and rehabilitation of the 44 hectares mangrove forest, the condition now becomes: (1) the home residents in coastal areas are no longer flooded by the sea level rise because the mangrove trees are already flourished and the location of the fish ponds are no longer damaged. (2) The conditions of the wells can be used again for watering the plants and washing. (3) The farmland is already well and thrive. (4) The livelihoods of coastal communities are well enough, so it could increase the income of the local economy. (5) The fishermen do not need to go far to look for fish because the surrounding area is already full of fish as if saving the fuel. (6) Many housewives helping the husband to find some fish around the mangrove. (7) the housewives could sell mangrove fruits for the farmer groups each for Rp.50. (8) People can utilize mangrove fruits to be produced as mangrove coffee. (9) In order to fill the kids' spare time/vacation, the kids could do some fishing activities around the mangrove.

With the help of mangrove flowers, there are a lot of bee food supplies. Flower honey bee production activity is the development of Mangrove plant, it can increase the income and support the funding in the preservation of mangrove plants in coastal areas. It is implemented annually from August until December because it is the spring months for Mangrove tree. Besides honey, Mangrove is also able to produce coffee seeds. From that, it can show us that the benefits of Mangrove are a lot, it can support the necessities of life and daily behavior of the coastal area community.

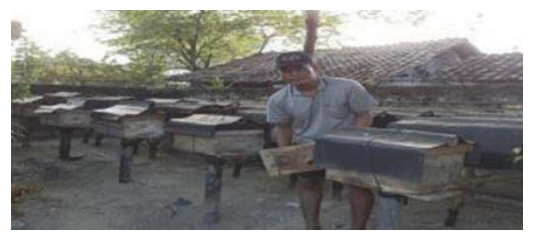

Figure 2: Mangrove Honey Cultivation

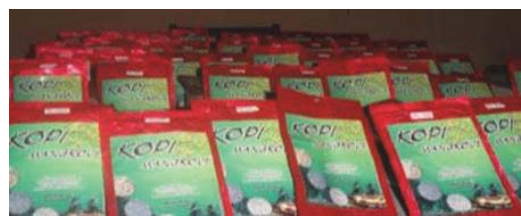

Figure 3: The Results of Mangrove Coffee 
The impact of the activities in terms of economic aspects: (1) Increase the income for the coastal areas communities in particular and the people of Pamekasan. (2) Increase the scope of the job site because Mangrove plants have many benefits in life. (3) Reduce the outcome of the coastal communities each year in one season for about Rp.2.5 million up to Rp.5 million in the improvement of salt farm and fish ponds. (4) Increase the economic income of the coastal area communities in the fishing and fish ponds sectors. (5) agricultural land becomes a productive land so that farmers can harvest the farm as expected. (6) return the water sources (wells) which were salty so that it can be used again by the residents of coastal communities.

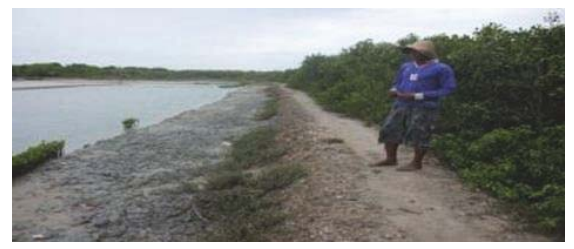

Figure 4: Fish Pond That Saved by the Green Belt Mangrove Forests

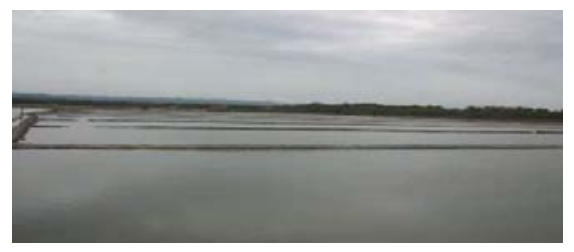

Figure 5: Salt Farm Which was Saved by the Green Belt Mangrove Forests

The impact of the activities in the socio-cultural aspects: (1) The realization of the good social-cultural condition in all components of the coastal areas. (2) The security of the residential area from abrasion. (3) The realization of Mangrove plants that can be used as the basis of research in the drug production manufacture. (4) The creation of aesthetic value (beauty) in coastal locations where it can be developed into domestic ecotourism in Pamekasan. (5) Increase the knowledge in the environmental field both for the present generation and future generation. (6) The realization of environmentally friendly Mangrove plants in coastal areas.

The impact of activity on the environment aspects: (1) There is a change in the original wells which used to be salty but now became tasteless so that it can be used for daily necessities, there is not much water which could be saved. (2) With the condition of dense mangrove forests, the air in the surrounding area is cooler now and it could support the activities in the area, it also can withstand the brunt of the high winds and waves. (3) Mangrove is very helpful for the stability of the ground, particularly the coastal areas where abrasion often occurs there. If the mangrove forest is dense, birds and other animals will feel comfortable to live inside the forest.

The fishing communities think that natural environment needs to be preserved especially mangrove forests as they relate to their welfare and their descendants. Since 2009, they were able to make big changes in critical and high abrasion coastal areas by planting mangrove trees around their shores. It is also not being separated from the role of local government, especially the Department of Marine of Pamekasan which often provide counseling and guidance for mangrove forest conservation activities. The government, in this case, the Department of Marine, has installed a sign warning for the tourists around the mangrove forest conservation associated with the sanctions for those who did not obey. They type of the mangroves which are used for the reforesting in coastal areas of Lembung, Kecamatan Galis, Kabupaten Pamekasan, among others: Tinjang, Prepat, Api-api.

\section{Discussion}

The impact of climate change that needs the attention from Indonesian people includes the changes of rainfall patterns which could lead to droughts, floods and sea levels rise. It can have an impact on the social, economic, cultural and political system. This impacts significantly affect the social life, especially in coastal areas. There was also an effect on 
the land reduction in coastal areas, the hydrological cycle and the system of water arrangements due to floods or a long dry season (droughts) (Anonymous in Gusmailina, 1997).

Sea-level rise is generally resulted in these following effects: (a) the increase in the frequency and intensity of the floods, (b) the changes in ocean currents and the damage in mangrove forests, (c) the expansion of sea water intrusion, (d) a threat to the socio-economic activities of the society, the reduce of land area and the loss of small islands (Bengen, 2002).

Besides the changes in ocean currents due to sea level rise, there is also a destruction of the mangrove ecosystems which its current condition is very severe. The extensive of mangrove forests in Indonesia continues to decline. In a period of 10 years (1982-1993), there has been a decline in mangrove forests approximately 50\% of its original area. If the existence of mangrove forests is not maintained, severe abrasion will occur because there is no wave barrier, the pollution of the river to the sea will rise because of there is no pollutants filter, and the cultivation zone will be threatened.

The particular complex issue is about the awareness and knowledge of the society. Climate change that is caused by greenhouse gasses is not easily explained to the public. The impact of climate change also cannot be predicted accurately and the changing process cannot be felt by the public at large. This situation makes the people difficult to imagine and understand the problems of climate change on impacting their lives. In this situation, the role of education is very needed, particularly the role of geography education to provide insight to the public correctly (Sumarmi, 2014).

As for the protected areas, the handling priority should be given to coastal border, riverbanks, mangroves, coral reefs, wildlife reserves / nature reserves / habitat for floras and faunas, and areas that are ecologically sensitive or have a high vulnerability to natural changes. For small islands, the protection should be given to the islands that have special functions, such as the island which is used for the transit point for floras-faunas and rare / protected habitats, used for the interests of defense, and so on.

Indonesia is located along the equator specifically in the "heart" of the Coral Triangle where its geographical characteristics make the marine and coastal environment of Indonesia become a suitable habitat for the growth of mangroves and seagrass beds. Indonesia has 3.1 million hectares of mangrove ecosystems or $23 \%$ of the world mangrove and the biggest seagrass beds in the world which are 30 million hectares. This can make a significant contribution to reducing the impact of climate change, not only for coastal and marine ecosystems but also for the terrestrial environment. "The number of high carbon showed that mangrove ecosystems can play an important role in mitigating the climate change. Marine and Fisheries Minister, Sharif Cicip Sutardjo in a written statement received by AFP in Jakarta, Thursday, May 15, 2014.

The vulnerability due to climate change in certain coastal areas influenced by three factors as follows: (1) The nature and magnitude of climate variabilities and changes, (2) human capital, and (3) the capacity of the current coastal communities to adapt and cope with climate changes. Meanwhile, the main objective of the adaptation program in coastal areas includes: (1) optimize the coastal ecosystems to be healthy and functioned optimally, (2) reduce exposure and vulnerability to the built environment, (3) strengthen the government framework for beach adaptation, (4) nurture the opportunities and diversification, and (5) reduce the risks that threaten the safety and human health (Kusnanto, 2011). The attempt of the communities in Madura to reduce the disaster due to sea level rise is by using a local wisdom that is cooperating together with farmer groups to manage the mangrove forests (Sumarmi, 2015).

Management and conservation of coastal and marine areas during the last 4 years is co-implemented by the Government of Indonesia, namely the Ministry of Marine and Fisheries. 2014 is the final year of the implementation of the National Medium Term Development Plan 2010-2014 (Rencana Pembangunan Jangka Menengah Nasional or RPJMN). The Ministry of Marine and Fisheries (2015) has implemented five of the eleven national development priorities. The marine and fisheries development is carried out in order to realize the four pillars of development, namely pro-poor (poverty alleviation), pro-job (employment), pro-growth and pro-environment (restoration and preservation of the environment).

This research was also supported by the results of Romadhon (2015) which pointed out: 1) the existence of the pond, new residential, agricultural expansion and the lack of knowledge of mangroves as the Drivers (D); conversion, clearing, mangrove logging, coastal reclamation and undervaluing the mangroves as Pressures $(P)$; land decreasing, mangrove destruction, overexploitation, water quality and changes in the wave patterns as State Change (S); sedimentation, domestic waste, coastal erosion and the pollution of water and soil as Impact (I); rehabilitation, mangrove ecotourism, Silvofishery and the formation of community groups as Response (R); 2) sustainable mangrove management is done through the establishment of community groups, rehabilitation, Silvofishery, and ecotourism.

The research of Seifu (2016) concluded that the majority of farmers in the study area are aware of climate change patterns and their adverse effect on income, food security, diversity, forest resources, food prices and crop and livestock 
diseases. In response to these adverse effects, major adaptation strategies used by farmers include cultivating different crops, planting different crop varieties, changing planting dates, use of soil and water conservation techniques, conservation agriculture practices and engaging in non-farm income activities.

A key finding is that despite vulnerability to climate change, climate change literacy is low and is influenced by multiple variables such as household income, the level of educational attainment, access to technology, governance structures and political commitment to communicating climate change. A major finding is that access to modern communication modes is limited and therefore verbal communication remains the most powerful means of transmitting messages on climate change. Moreover, opportunities exist for the use of participatory and indigenous communication techniques Mycoo (2015). Important adaptation options being used by farmers in response to adverse effects of climate change include crop diversification, planting different crop varieties, changing planting dates, use of water and soil conservation techniques, increased use of irrigation, conservation agriculture and diversifying from farm to non-farm activities (Seifu, 2016).

\section{Conclusion}

With the problems of climate change which are increasingly growing, it gives such noticeable impact on the changes of global climate conditions such as water crisis, the vulnerability of food security and the vulnerability of coastal ecosystems. To reduce the vulnerability and protect the ecosystem in coastal areas, increasing the knowledge, skills, attitudes, and ethics that cares about its ecosystem is very needed. This can only be done by building the public awareness to care about the environment.

\section{References}

Alexandra V, Dimitra Spyridi Christos Vlachokostas. Michailidou Constantinos Sioutas Nicolas

Moussiopoulos. 2015."Strategic planning for climate change mitigation and adaptation: the case of Greece", International Journal of Climate Change Strategies and Management, Vol. 7 Iss 3 pp. 272 - 289 http://radarmadura.co.id/2013/10/dishutbunkembangkan-kopi-dan-madu-mangrove.

Antara News Kamis, 15 Mei 2014 11:56 WIB.

Apridar, dkk. 2011. Ekonomi Kelautan dan Pesisir. Yogjakarta, Graha IImu.

Bengen, D.G. 2002.Sinopsis Ekosistem dan Sumbedaya Alam Pesisir dan Laut Serta Prinsip Pengelolaannya.Bogor: Pusat Kajian Sumberdaya pesisir dan Laut IPB.

Creswell, John W. 2010 Research Design (Pendekatan Kualitatif, Kuantitatif dan Mixed, Yogyakarta : Pustaka Pelajar.

Diposaptono S, Budiman, Firdaus A. 2009. Menyiasati Perubahan IKlim di Wilayah Pesisir dan Pulau-Pulau Kecil. Bogor (ID): PT. Sarana Komunikasi Utama.

Direktorat Jenderal Pesisir Dan Pulau-Pulau Kecil Departemen Kelautan Dan Perikanan. 2004.

Pedoman Mitigasi Bencana Alam di Wilayah Pesisir dan Pulau-Pulau Kecil. ISBN 979-3556-18-8.

Fachrul. http://tyasmelani.blogspot.com/2009/05/ekosistem-pesisir-pantai.html).

Gusmailina. 1997. Prakiraan Respon Hutan Terhadap Perubahan Iklim Terutama Akibat Peningkatan Konsentrasi $\mathrm{CO}_{2}$ Atmosfir. Jakarta. Info Hasil Hutan Vol. 4 Nomer 1: 16-26.

Indiyanto, Agus dan Kuswanjono, Arqom (Ed). 2012. Konstruksi Masyarakat Tangguh Bencana. Bandung: Mizan.

Intergovernmental Panel on Climate Change (IPCC) (2007), Climate Change 2007: Synthesis Report - Contribution of Working Groups I, II and III to the Fourth Assessment Report of the Intergovernmental Panel on Climate Change, Intergovernmental Panel on Climate Change, Geneva.

Kusnanto, Hari. 2011. Adaptasi perubahan iklim. Yogjakarta. BPFE

Mycoo, Michelle, (2015),"Communicating climate change in rural coastal communities", International Journal of Climate Change Strategies and Management, Vol. 7 Iss 1 pp. 58 - 75

Priwardhani. 2013. Ketika Kupu-Kupu Kuning Tak Lagi Muncul: Perubahan Iklim dan Pengetahuan Lokal di Dua Desa Pesisir Kabupaten Ende. Journal Transformasi Sosial - Wacana. 6 (29) : 113-135. Yogyakarta (ID) : Insist Press.

Seifu, Wondimagegn Tesfaye Lemma. 2016. Climate change perception and choice of adaptation strategies", International Journal of Climate Change Strategies and Management, Vol. 8 Iss 2 pp. 253- 270.

Sumarmi. 2012. Pengembangan Wilayah Berkelanjutan. Yogjakarta. Aditya Media ISBN 978-602-9461-75-6.

Sumarmi.2014. Pengelolaan Lingkungan Berbasis kearifan lokal. Yogjakarta. Aditya Media. ISBN 978-602.7957-50-3.

Sumarmi. 2014. Penerapan Etika Lingkungan Berbasis Kearifan Lokal Sebagai Upaya Pencegahan Kerusakan Lingkungan Dan Mengatasi Bencana Global. Malang. Proseding Seminar Nasional5 April 2014 UNIKAMA.

Sumarmi, 2014. Peran Pendidikan Geografi dalam Melindungi Pesisir dan Perubahan Iklim Global. Makalah disampaikan dalam Seminar Nasional di UNIKAMA Mei 2014.

Sumarmi. 2015. pengembangan ekowisata berbasis kearifan lokal dan implementasi revolusi biru untuk pemberdayaan masyarakat desa pesisir dalam era ekonomi global. malang. proseding seminar nasional 9 mei 2015 UNIKAMA. 
Undang-Undang Republik Indonesia Nomor 1 tahun 2014 Tentang Perubahan atas undang-undang nomor 27 tahun 2007 Tentang pengelolaan wilayah pesisir dan pulau-pulau kecil.

Undang-undang republik indonesia Nomor 1 tahun 2014 Tentang Perubahan atas undang-undang nomor 27 tahun 2007 Tentang pengelolaan wilayah pesisir dan pulau-pulau kecil.

Seifu,Wondimagegn Tesfaye Lemma 2016."Climate change perception and choice of adaptation strategies", International Journal of Climate Change Strategies and Management, Vol. 8 Iss 2 pp. 253- 270.

Wibowo, Ari dan Satria, Arif. 2015. Strategi Adaptasi Nelayan di Pulau-Pulau Kecil terhadap Dampak Perubahan Iklim (Kasus: Desa Pulau Panjang, Kecamatan Subi, Kabupaten Natuna, Kepulauan Riau). Jurnal Sosiologi Pedesaan |Agustus 2015, hal 107-124.|

Undang-Undang Republik Indonesia nomor 24 tahun 2007. Tentang Penanggulangan Bencana. http://tyasmelani.blogspot.com/2009/05/ekosistem-pesisir-pantai.html

https://rendezvoustrip.wordpress.com/2014/04/14/kopi-mangrove-kopinya-malam-jumat

http://ilmukelautan.trunojoyo.ac.id/wp-content/uploads/2015/03/15.Romadhon.-A.-pada-KoNas-IX-Pengelolaan-SumberdayaPesisirLaut-dan-Pulau-pulau-Kecil-Konas-IX-2014.pdf 